\title{
INTERGALAKTINEN BRITTI-IMPERIUMI TÄHTIEN SOTA -TRILOGIASSA
}

Brittiläis-amerikkalaisen komediaryhmä Monty Pythonin englantilaisjäsen Michael Palin (s. 1943) kertoo päiväkirjamerkinnässään vuodelta 1977, miten tämä vei poikansa katsomaan uusinta James Bond -elokuvaa Rakastettuni (The Spy Who Loved $M e$, Lewis Gilbert, 1977). Palinin mielestä elokuva oli "tyhjänpäiväistä roskaa, josta Britannialla ei ole mitään syytä olla ylpeä". Sen sijaan hänen aiemmin näkemänsä "amerikkalainen tieteiselokuva" Tähtien sota (Star Wars, George Lucas, 1977) oli "paljon, paljon parempi seikkailu. (Palin 2006, 475; ks. myös Sandbrook 2012, 86; Mähkä 2016, 221-222.) $)^{2}$

Tähtien sodalla jatko-osineen ${ }^{3}$ (Imperiumin vastaisku [The Empire Strikes Back], Irvin Kershner, 1980, sekä Jedin paluu [Return of the Jedi], Lucas 1983) ja James Bond -elokuvilla on kuitenkin paljon muutakin yhteistä kuin seikkailullisuus. Molemmissa on paljon brittinäyttelijöitä ja imperiumeilla on niissä tärkeä, joskin erilainen merkitys. Bond-elokuvissa brittiagentti seikkailee ympäri entisiä siirtomaita ja puolustaa kutistuneen imperiumin etuja ja kunniaa. Tähtien sota -elokuvissa imperiumi on puolestaan paha galaksienvälinen imperiumi, joka on alistanut planeetat ja niiden asukkaat valtaansa ylivoimaisen sotakoneistonsa avulla. ${ }^{4}$

Tarkastelemme tässä artikkelissa Tähtien sota -universumin imperiumia mielikuvituksellisena tulkintana Yhdysvaltojen ja Britannian historiasta. Taustalla on havainto siitä, että elokuvien pahan "ensimmäisen galaktisen imperiumin" ("First Galactic Empire") keisari ${ }^{5}$, hallintovirkamiehet sekä upseeristo puhuvat lähes poikkeuksetta

\footnotetext{
1 Käytämme kursiivia (Tähtien sota) viitatessamme ensimmäiseen Tähtien sota -elokuvaan. Muulloin kyseessä on yleisviittaus elokuvasarjaan ja sen tarinamaailmaan.

2 Artikkeli on osa Suomen Kulttuurirahaston Varsinais-Suomen rahaston rahoittamaa tutkimushanketta "Empire of the Mind": Brexit, Media and Heritage, 1979-2019.

${ }^{3}$ Käsittelemme artikkelissa vain näitä vuosina 1977-1983 ilmestyneitä elokuvia, sillä niiden voi katsoa syntyneen tiettynä historiallisena aikakautena. Seuraava Tähtien sota -elokuva ilmestyi 16 vuotta Jedin paluun jälkeen, vuonna 1999 (Episode I: The Phantom Menace, Lucas).

${ }^{4}$ Lucas kertoi vuonna 1973 Filmmakers Newsletterille, että hän työskenteli ulkoavaruuteen sijoittuvan elokuvaidean parissa, joka oli "sekametelisoppa scifi- / Flash Gordon -genren elokuvista, 2001: Avaruusseikkailusta ja James Bond -elokuvista". Sit. Jones 2016, 209. Huomionarvoista tämän artikkelin kannalta on Bond-inspiraatio, sillä myös Palin siis yhdisti Tähtien sodan ja James Bondin jossa ei ollut avaruusteemaa - toisiinsa.

${ }^{5}$ Lucas teki vuonna 1967 opiskelijatyönä elokuvan nimeltä The Emperor, joka tosin kertoi losangelesilaisesta radiojuontajasta. Hän teki samaan aikaan scifielokuvaa THX1138, joten ehkä Tähtien sodassa hän alitajuntaisesti yhdisti teemat - scifin ja keisariuden - toisiinsa. Mainituista elokuvista ks. Jones 2016, 100-105.
} 


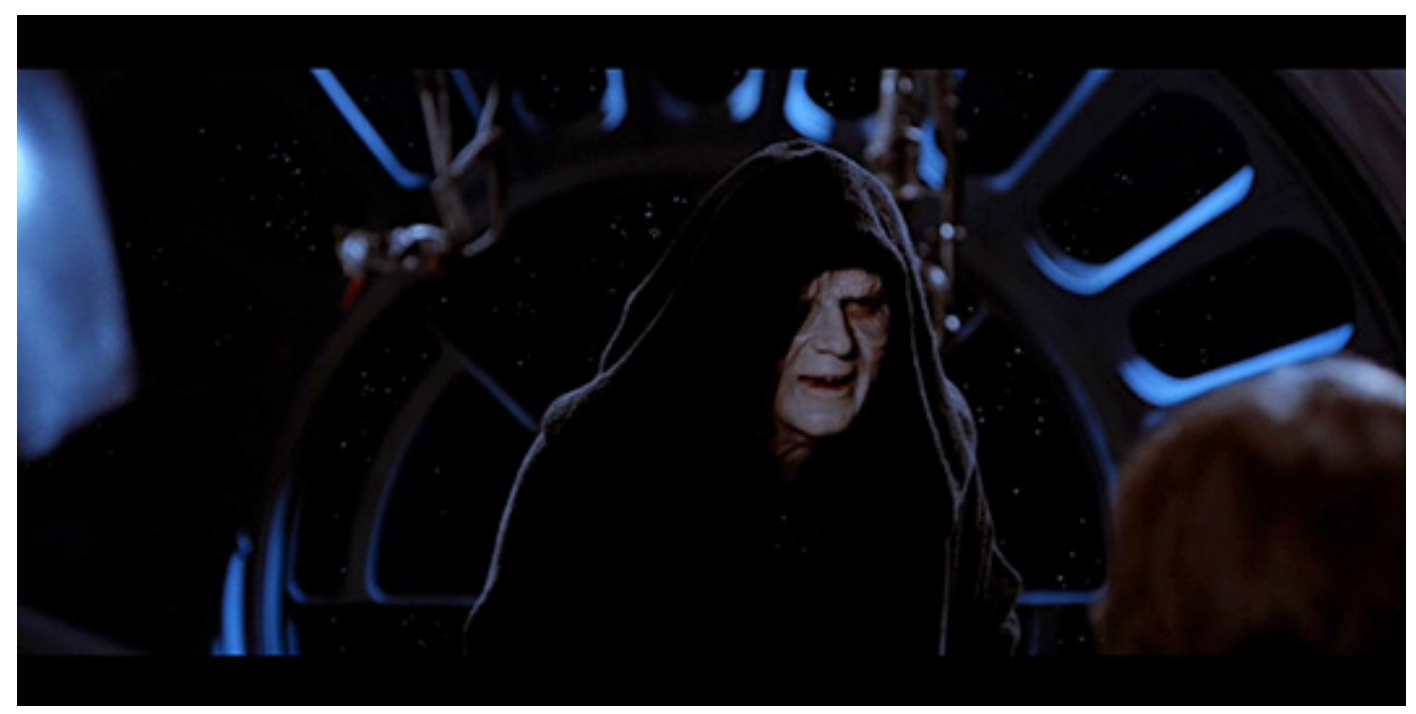

Ikääntynyt, ylimielinen keisari Palpatine (skottinäyttelijä lan McDiarmid) ei ymmärrä kapinaliikkeen "nousukasmaista" dynamiikkaa ja hänen imperiuminsa tuhoutuu sen seurauksena. Kuva: Kuvakaappaus DVD:Itä.

englantilaisilla, keski- ja yläluokkaisilla aksenteilla, kun taas pääosa Imperiumia vastaan taistelevan Kapinaliiton ("Rebel Alliance") jäsenistöstä, johon elokuvien päähenkilöt Luke Skywalker (Mark Hamill), Han Solo (Harrison Ford) ja prinsessa Leia Organa (Carrie Fisher) kuuluvat, puhuu amerikkalaisilla aksenteilla.

Vaikka Hollywood-elokuvan konventioihin on pitkään kuulunut, että normaaleista rikollisista poikkeavat "pahikset" puhuvat ei-amerikkalaisilla aksenteilla (britit, saksalaiset, venäläiset ja niin edelleen), minkä ilmiselvä tarkoitus on toimia toiseuttavana elementtinä, Tähtien sota -elokuvissa nimenomaan koulutetuilta kuulostavat britti- tai pikemminkin englantilaisaksentit luovat erityisen historiallisen kontekstin. Toki osasyy vahvaan brittiedustukseen elokuvissa on se, että elokuvat tehtiin pitkälti Englannissa, pääosin kustannussyistä.

Artikkelimme otsikon "intergalaktinen britti-imperiumi" viittaa näkökulmaamme, eli siihen, että Tähtien sota -elokuvien tarinamaailman imperiumi on "brittiläinen" sen johtajiston vahvasti englantilaisen aksentin takia. Yhdysvaltalainen käsitys brittiimperiumista on siirretty "toiseen galaksiin", ja Tähtien sodan Imperiumi puolestaan vaikuttaa käsityksiin sekä historiallisesta britti-imperiumista että sitä vastaan taistelevista kapinallisista, jotka assosioituvat pohjoisamerikkalaisiin. Päinvastoin kuin pelkästään valkoihoisista ihmisistä - ja vain miehistä - koostuva Imperiumi, Kapinaliitossa toimii korkeissa asemissa myös naisia ja "toislajisia". Kapinaliitto on, erityisesti sarjan kolmanteen elokuvaan tultaessa, hyvin monikulttuurinen, vastaten huomattavasti paremmin 1970-luvun kuin 1700-luvun lopun amerikkalaisuutta.

\section{Tähtien sota amerikkalaisen ja brittiläisen kulttuurin yhteentörmäyksenä}

Erityisesti ensimmäisen elokuvan tekeminen oli kaikkea muuta kuin kitkatonta Lucasin ja brittihenkilöstön välillä: britit, jotka pitivät tiukasti kiinni ammattiliiton säännöksistä työskentelyaikoineen ja teetaukoineen, naureskelivat avoimesti "koiralle" (Chewbacca) ja äänettömien muovipyssyjen kanssa heiluneille näyttelijöille. Han Soloa näytelleen Harrison Fordin mukaan britit pitivät elokuvaa naurettavana, Lucas puolestaan koki, että nämä suhtautuivat häneen "hulluna amerikkalaisena, 


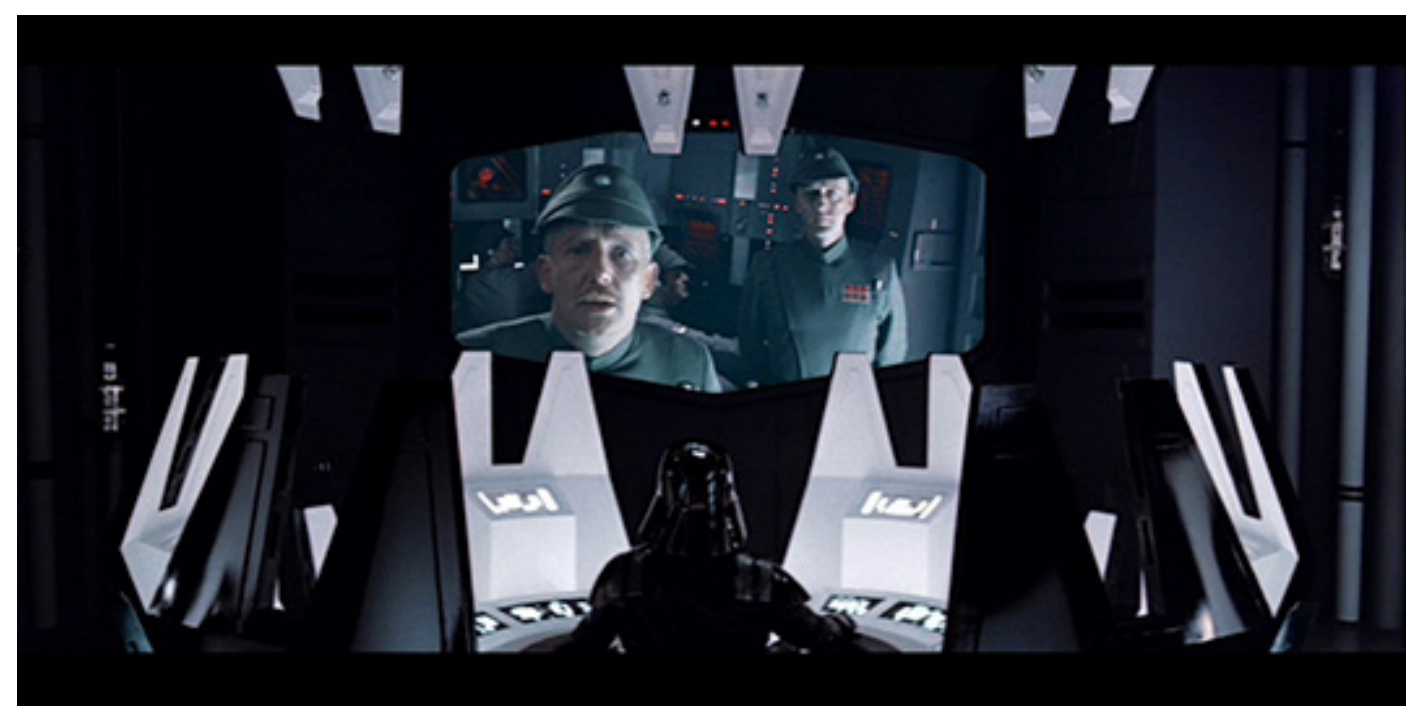

Tärkeilevä, luokkatietoinen amiraali Ozzel (skottinäyttelijä Michael Sheard) on tuottanut pettymyksen kärsimättömälle Darth Vaderille (David Prowse / James Earl Jones) viimeisen kerran. Kuva: Kuvakaappaus DVD:Itä.

joka ohjasi aivan höperöä elokuvaa". Naljailua esiintyi myös britti- ja amerikkalaisnäyttelijöiden kesken. Obi-Wan Kenobia esittänyt Alec Guinness pyöritteli avoimesti silmiään Lucasille käsikirjoituksen dialogista, ja sai ilmeisesti muutettua sitä mielestään vähemmän huonoksi. (Sit. Jones 2016, 280, 285; Rare Star Wars 1977 Alec Guinness Interview 2014; O'Brien 2000, 137-138.)

Brittilehti Telegraphin Chris Bell (2019) kuvaa sinänsä ammattitaitoisen brittituotantotiimin asennetta sarkastiseksi ja jopa vihamieliseksi. Kun Tähtien sodan loppukohtauksen mitaliseremoniassa sankarihahmot astelivat kohti prinsessa Leiaa, yksi brittiekstroista kivahti, "wankers!" Jedin paluun ohjaajan poika, James Marquand, muistaa puolestaan, miten ewokien ${ }^{6}$ brittinäyttelijät olivat kuvaustauolla kokoontuneet, rooliasun pään riisuneina, juomaan teetä, kiroilemaan ja tupakoimaan (Marquand: "hyvin brittiläistä") (sit. Bell 2019). Lucasfilm-yhtiön Kaliforniassa järjestämillä grillijuhlilla amerikkalaiset pitivät siistiä piknikiä, kun taas britit kokoontuivat uima-altaalle "juopumaan hitaasti". Walesilaisen Marquandin mielestä kyseessä olivat esiin tulleet kulttuurierot, joita Bellin mukaan Lucas ei laajemminkaan ymmärtänyt.

Britit sanoivat Lucasille ja tämän johtoryhmälle suoraan, mitä ajattelivat, mikä oli epätavallista amerikkalaistiimiläisille. Toisaalta amerikkalaiset - mukaan lukien elokuvien päätähdet - pitivät Englantia tylsänä, kalseana, rumana ja masentavana paikkana ja he myös sanoivat sen ääneen. Luke Skywalkerin esittäjä, Mark Hamill, esitti ehkä provosoivimman väitteen, jonka mukaan briteillä ei ollut "todellista science fiction -viitepistettä", mikä lienee pöyristyttänyt brittejä. Vain brittiläinen pubikulttuuri vetosi amerikkalaisiin. (Bell 2019.) Kaikki tämä osoittaa, miten elokuvassa sekä sisällöllisesti että tuotannon tasolla olivat läsnä entisen siirtomaaisännän, toisen luokan maailmanmahdiksi kutistuneen maan, ja sen poliittisen ja kulttuurisen hegemonian haltuunsa ottaneen entisen siirtokunnan edustajien yhteistyö ja

\footnotetext{
6 Bellin (2019) mukaan kaikki paitsi Lucas vihasivat ewokeja. Ohjaaja Marquand yritti viimeiseen asti saada Lucasin muuttamaan mielensä niiden sisällyttämisestä elokuvaan. Lucas perusteli päätöstään pitää ewokit liiketaloudellisista syistä, sillä hän uskoi niiden lapsiin vetoavaan potentiaaliin.
} 
yhteentörmäys. Tämä vastakkainasettelu on vaikuttanut myös elokuvan tekoon osallistumattomien näkemyksiin.

Brittiscifihistorioitsija O'Brienin (2000, 137-138) mielestä brittinäyttelijöiden ja -henkilöstön panos Tähtien sodalle oli niin suuri, että sen voi lähes sanoa kantavan "Made in England"-leimaa, vaikka hän toteaakin, että elokuvien "ilme" on kiistattoman amerikkalainen, johtuen etenkin "kalifornialaisesta fantasia-auteurista", George Lucasista. O’Brien näkeekin elokuvat pohjimmiltaan "gung ho -henkisenä amerikkalaisscifinä", jossa hyvä ja paha ovat selväpiirteisesti erotettu toisistaan ja hyvän on lopulta voitettava todennäköisyyksistä huolimatta. Curtis $(1980,592)$ taas kiinnitti aikalaisartikkelissaan huomiota siihen, että suurin osa Tähtien sodan pääroolien näyttelijöistä oli lähes tai täysin tuntemattomia suurelle yleisölle Alec Guinnessia (Obi-Wan Kenobi) ja Peter Cushingia (Grand Moff Tarkin) lukuun ottamatta. Curtisin mielestä on kuitenkin "merkittävää", että viimeksi mainitut ovat brittejä, eikä amerikkalaisyleisöillä ole heistä vastaavia vahvoja "assosiaatioita" kuin suurista amerikkalaisista filmitähdistä.

Vaikka Curtis (ibid.) tarkentaa, että John Waynen tai James Stewartin kiinnittäminen huomattavaan sivurooliin olisi "häirinnyt" elokuvan "autonomiaa" [omaperäisenä luomuksena], väitämme, että samalla brittinäyttelijöiden ei-amerikkalaisuus esti heidän hahmojensa nousun yleisön samastumiskohteiksi. Viisas vanhus (Kenobi) ja pahan imperiumin kuvernööri (Tarkin) olivat luontaisia hahmoja ulkomaalaisten näyttelijöiden rooleiksi. Ensin mainittu hahmo edustaa "vanhaa maailmaa" (Old World, eli amerikkalaisittain Eurooppa), viimeksi mainittu alistavaa Imperiumia (brittiläinen imperiumi).

\section{"Brittiläinen" Imperiumi, "amerikkalainen" Kapinaliitto}

Vaikutteet Tähtien sodan Imperiumin ja tätä vastaan taistelevan kapinaliikkeen konfliktin välillä on tulkittu eri tavoin, ja erot tulkintojen välillä ovat hedelmällisiä pohdittaessa historian ja kulttuuriperinnön vaikutusta elokuvien ymmärtämiselle. Yhdysvaltaintutkija McVeigh $(2006,55)$ kirjoittaa, että Tähtien sota -elokuvien "ekstaattinen" vastaanotto Britanniassa selittyy vaikeuksilla, joita Britannialla oli ollut 1970-luvulla talousongelmineen, työttömyyksineen ja suurine lakkoineen. Tähtien sodan kaltainen eskapistinen fantasia tarjosi siis lohtua 1970-luvun synkkyyteen (ks. myös Mähkä 2016, 37-38, passim.). Tämä on varmasti totta, mutta McVeighin väite, jonka mukaan hänen Tähtien sodan kontekstina näkemänsä Vietnamin sota ja Yhdysvaltojen kylmän sodan ajan sotilaallinen toiminta olivat "tuskin lainkaan relevantteja brittiyleisöille" (McVeigh 2006, 55), on mielenkiintoisempi. ${ }^{7}$ Mielestämme fokusoimalla tarkastelun kylmän sodan ajan Yhdysvaltoihin McVeigh rajaa pois kaikkein selkeimmän allegorisen tason, eli Yhdysvaltojen itsenäistymisen historian, jonka ytimessä oli taistelu imperiumia vastaan.

Bell (2019) kirjoittaakin, miten Amerikan vallankumous [1765-1783, jonka seurauksena Pohjois-Amerikan siirtokunnat irtautuivat brittiläisestä imperiumista] oli läsnä Imperiumin vastaiskun kuvauksissa, mikä aiheutti närää brittihenkilöstön keskuudessa. Amerikkalaisaksenteilla puhuva sankarillinen Kapinaliitto taisteli pahaa Imperiumia vastaan. Viimeksi mainitun upseerit puhuivat "terävän asiapitoista [yläluokkaan assosioitavaa] Kuningattaren englantia" ("clipped Queen's English"). Lopputulosta vahvisti päätös jälkiäänittää brittinäyttelijöiden esittämien

\footnotetext{
7 Wilhelm $(2006,182)$ näkee Tähtien sodan yhtenä inspiraationa USA:ta vastaan esitetyt syytökset "imperialistisesta laajentumisesta kansainvälisillä areenoilla".
} 
kapinallispilottien dialogi amerikkalaisnäyttelijöillä, jotta päästiin eroon "toisen maailmansodan RAF-tunnelmista". Tavallista kansaa edustaneiden sankaripilottien tuli puhua amerikanenglantia. Nimenomaan tämä vastakkainasettelu on Tähtien sodan universumin poliittisen asetelman ytimessä.

Keisari Palpatine (näyttelijä), tämän lähes koko esikunta (asiaan palataan alla) sekä Imperiumin armeijan upseeristo puhuvat siis brittienglantia, ja nimenomaan koulutetulla, keski- ja yläluokkaisilla aksenteilla. Kuten brittihistorioitsija Dominic Sandbrook (2012, xiii-xv, xvii) kirjoittaa, Tähtien sodan konnahahmo, Imperiumin superasetta, tekoplaneetta Kuolontähteä, komentava Grand Moff Tarkin on "brittisiirtomaavirkamiehen malliesimerkki, viileän järkähtämätön loppuun asti”. Tarkinia esittää 1950-1970-luvuilla varsinkin brittiläisen Hammer-yhtiön kauhuelokuvissa

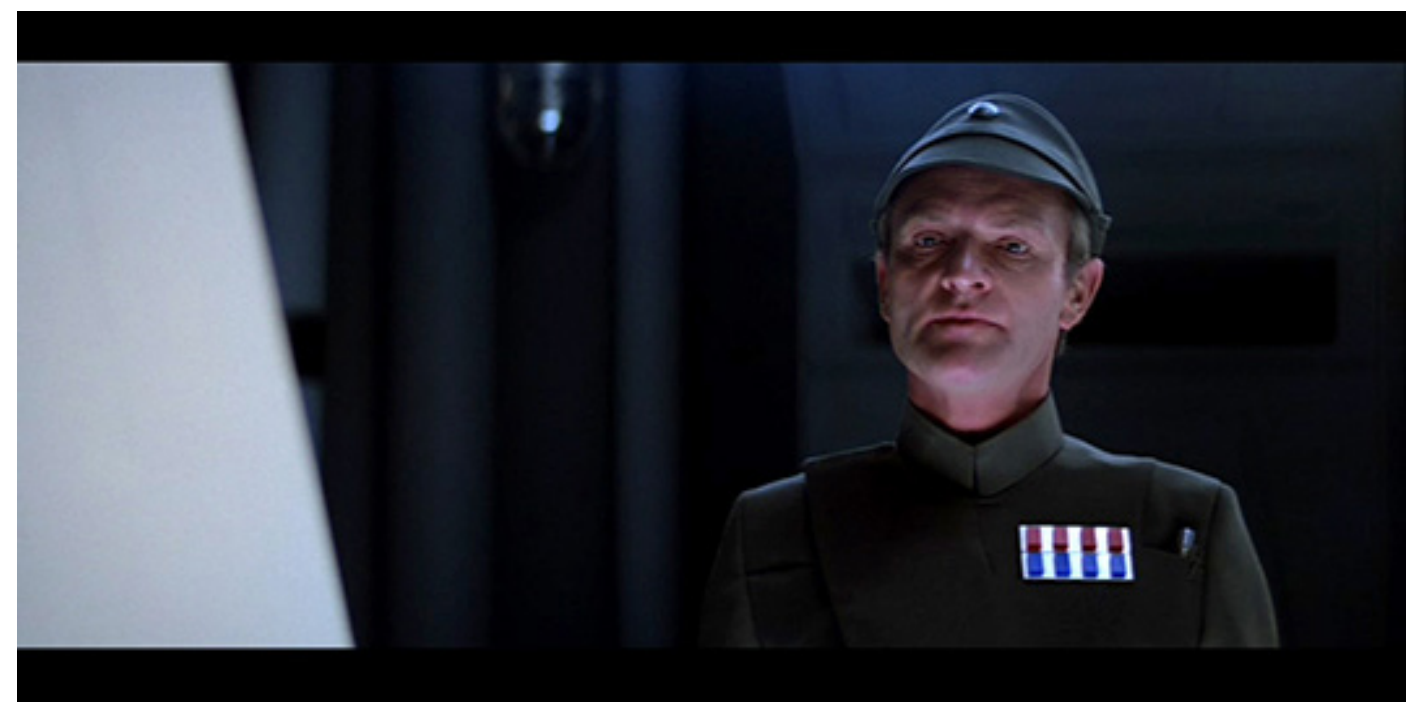

Kenraali Veers (klassisen näyttelijäkoulutuksen saanut englantilainen Julien Glover) edustaa kylmän viileää imperiumin ammattiupseerityyppiä. Kuva: Kuvakaappaus DVD:Itä.

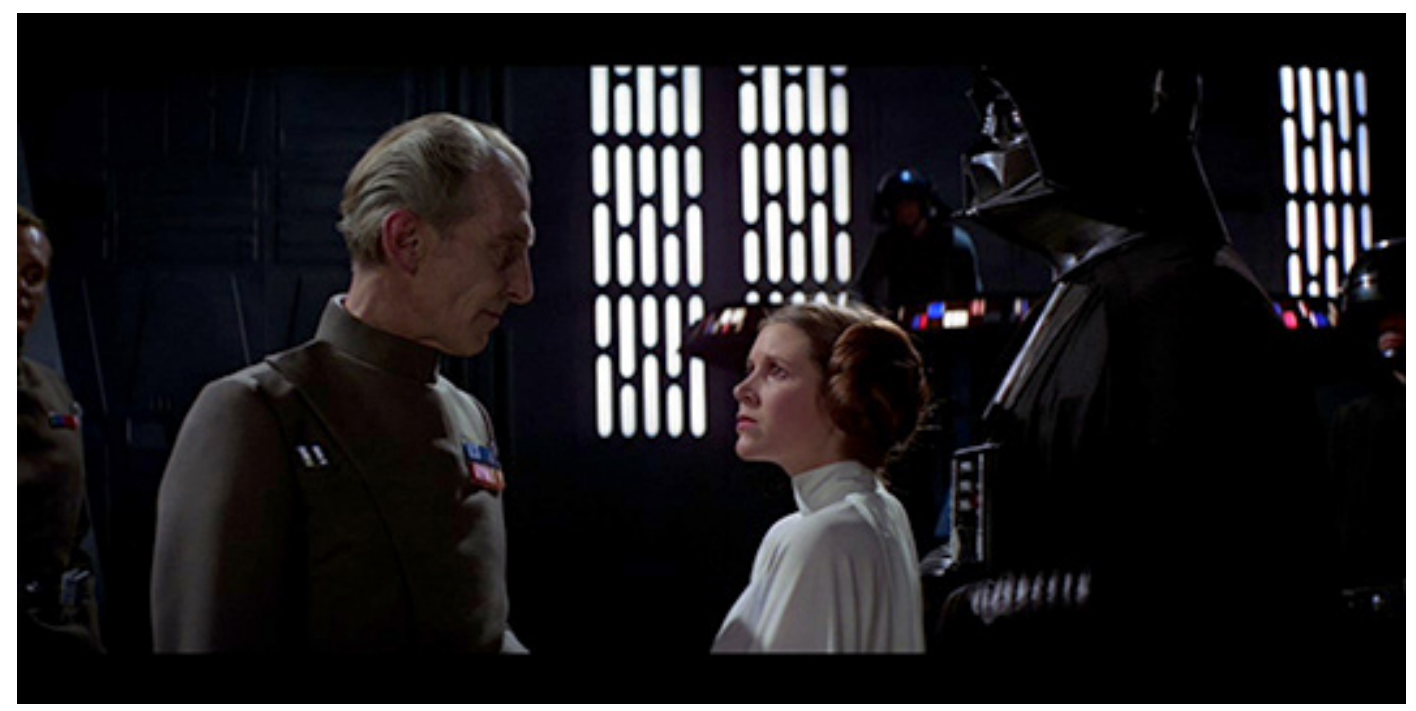

Kuolontähden "brittiäinen" komentaja, Grand Moff Tarkin (Peter Cushing) (vasemmalla), kuulustelee "amerikkalaista" kapinaprinsessaa Leia Organaa (Carrie Fisher) (keskellä). Darth Vaderia (oikealla) esittäneen brittinäyttelijä David Prowsen repliikit korvattiin jälkiäänityksessä amerikkalaisella James Earl Jonesilla. Kuva: Kuvakaappaus DVD:Itä. 
maineensa luonut Peter Cushing (1913-1994), joka tunsi sen kulttuurin, jonka kouluttamana imperiumin palvelukseen lähdettiin. On mahdoton tietää, kuinka tietoinen Lucas oli tästä kontekstista tai Cushingin hahmon brittikulttuurista ponnistavasta historiallisesta autenttisuudesta, mutta Cushing itse vitsaili, että näytteli elokuvassa "hyvin epämiellyttävää herrasmiestä" pukeutuneena kuin "edvardiaanisen ajan autonkuljettaja"8 (Peter Cushing on playing Grand Moff Tarkin [...], 2016).

Analyysi Imperiumin henkilöstön aksenteista paljastaa, että jako britti-ja amerikkalaisaksentteihin on erittäin hierarkiasidonnainen. Keisarista alaspäin lähes kaikki ylemmät virkamiehet ja upseerit puhuvat koulutetuilla brittiaksenteilla. Merkittävin poikkeus tästä on Tähtien sodan amiraali (Richard LeParmantier), sokeasti teknologian ja aseellisen ylivoiman varaan laskeva hahmo, joka kyseenalaistaa Vaderin vaaliman Voiman - traditioksi ja kulttuuriperinnöksi ymmärrettävän filosofian - merkityksen. Imperiumin vastaiskussa, joka kuvaa enemmän Imperiumin näkökulmaa kuin kaksi muuta elokuvaa, brittiaksenttien läsnäolo vain vahvistuu, kun tarinaan tulee mukaan imperiumin upseeristoa ylimielisestä amiraali Ozzelista (Michael Sheard) maavoimien kenraali Veersiin (Julien Glover). Argumenttimme on, että brittinäyttelijät puhuivat regionaalisten murteiden - esimerkiksi edellä mainittu Shread on skotti - sijaan koulutetuilla englantilaisaksenteilla siksi, että he esittivät korkeaa upseeristoa. ${ }^{9}$ Tämä oli näkemyksemme mukaan luonnollinen ratkaisu, sillä he itse olivat sen maailman kasvatteja, joissa vastaavassa asemassa olevat henkilöt puhuivat niin. Historia ja kulttuuriperintö "sanelivat" puhetavan.

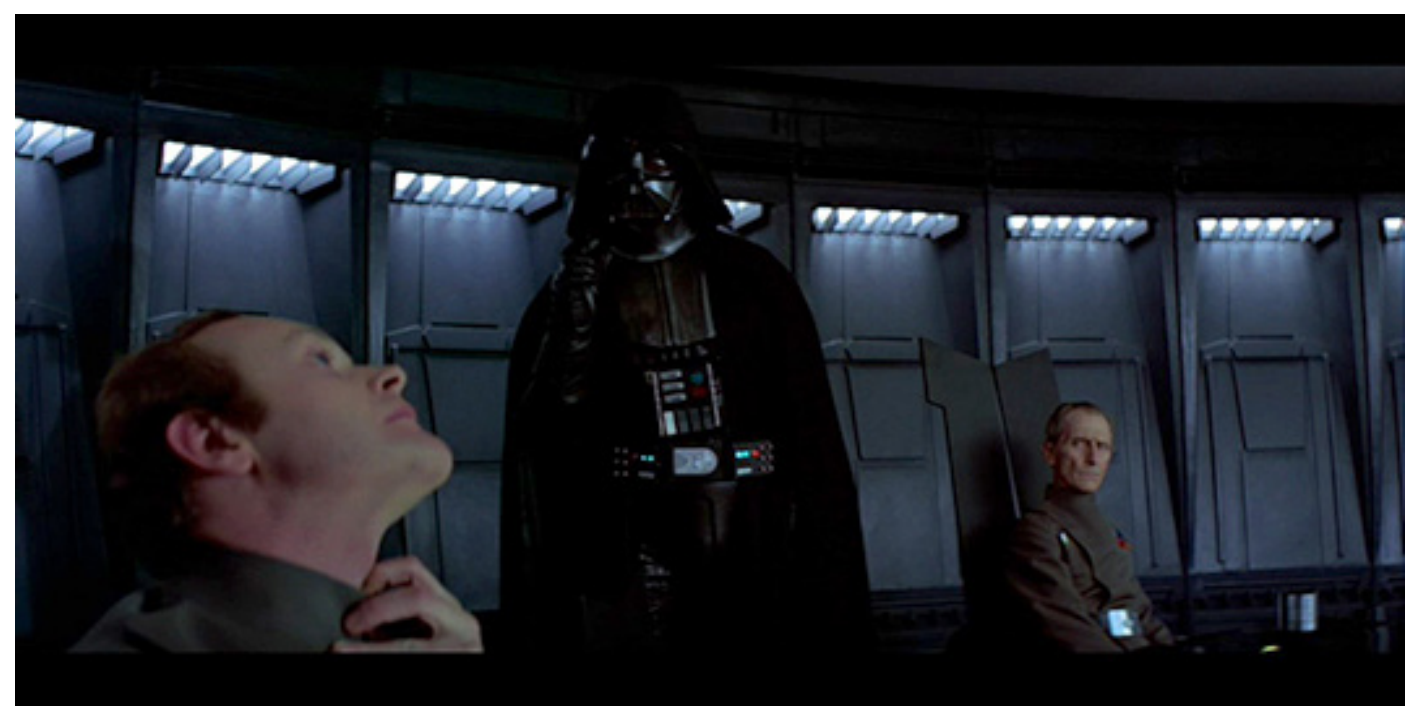

Amerikkalaisella aksentilla puhuva teknologiauskovainen Imperiumin amiraali (Richard LeParmantier, vasemmalla) saa osoituksen kulttuuriperinnön voimasta langenneelta jediritari Darth Vaderilta (David Prowse / James Earl Jones) elokuvassa Tähtien sota (1977). Kuva: Kuvakaappaus DVD:Itä.

\footnotetext{
${ }^{8}$ McVeighin $(2006,56)$ mielestä imperiumin upseeriston univormut ovat "ilmiselvästi" lainattu natsiSaksalta, mikä selittyy hänen mukaansa sillä, että Leni Riefenstahlin propagandaelokuvat vaikuttivat suuresti Tähtien sotaan. Ks. myös Brooker 2009, 78-79.

9 Vader on mielenkiintoinen tapaus, sillä amerikkalaisaksentistaan huolimatta hänen repliikeissään on tiettyä "transatlanttisuutta", erityisesti hänen tavassaan lausua luokkatietoinen sana "master", jossa on brittivivahde. Vader on poikkeustapaus, sillä hänellä ei ole mitään muodollista asemaa imperiumissa, vaan hän on keisari, Sith-lordi Palpatinen oppilas ja oikea käsi. Hän edustaa "vanhaa maailmaa", mikä tekee hänen aksenttinsa erityispirteistä viittauksen Yhdysvaltojen ja amerikanenglannin historiaan.
} 
Amerikkalaisaksentteja on ainoastaan alemmilla upseereilla ja miehistöllä. Armeijan miehistön ja aliupseeriston, iskujoukkojen (stormtroopers), tapauksessa amerikkalaisaksentit selittyvät pitkälti sillä, että kypäräpäisten hahmojen repliikit jälkiäänitettiin jälkituotantovaiheessa Yhdysvalloissa. Kapinaliikkeen aksentit ovat taas, johtajia myöden, lähes poikkeuksetta amerikkalaisia. Voidaan todeta, että brittija amerikkalaisaksentit eivät niinkään jakaudu horisontaalisesti vastakkainasettelun kautta (Imperiumi - Kapinaliitto) vaan vertikaalisesti: galaksia hallitsevissa asemissa olevat puhuvat koulutetuilla britti(englantilais)aksenteilla, heidän alapuolellaan (joihin kapinaliike kokonaisuutena väistämättä kuuluu) niin samalla kuin vastapuolella olevat amerikkalaisaksenteilla. Tämä muuttuu vasta Jedin paluussa: voimaansa selvästi kasvattaneen Kapinaliiton johto on kasvanut monikulttuuriseksi ryhmittymäksi, missä on "toislajisten" (kuten amiraali Ackbar) lisäksi brittienglantia puhuvia,

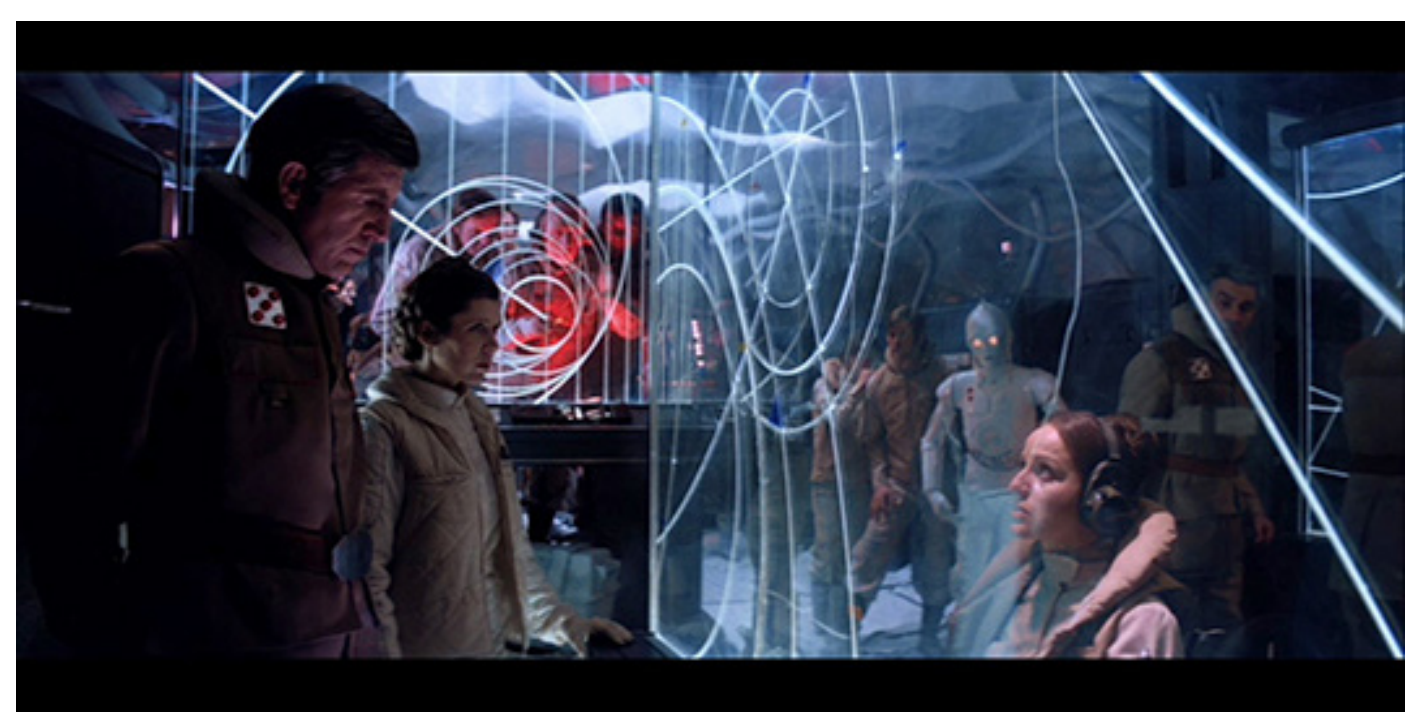

Imperiumin vastaiskussa (1980) Kapinaliiton tukikohdan johtokeskuksessa puhutaan vain amerikanenglantia Bruce Boan (vasemmalla) ja Carrie Fisherin johdolla. Kuva: Kuvakaappaus DVD:Itä.

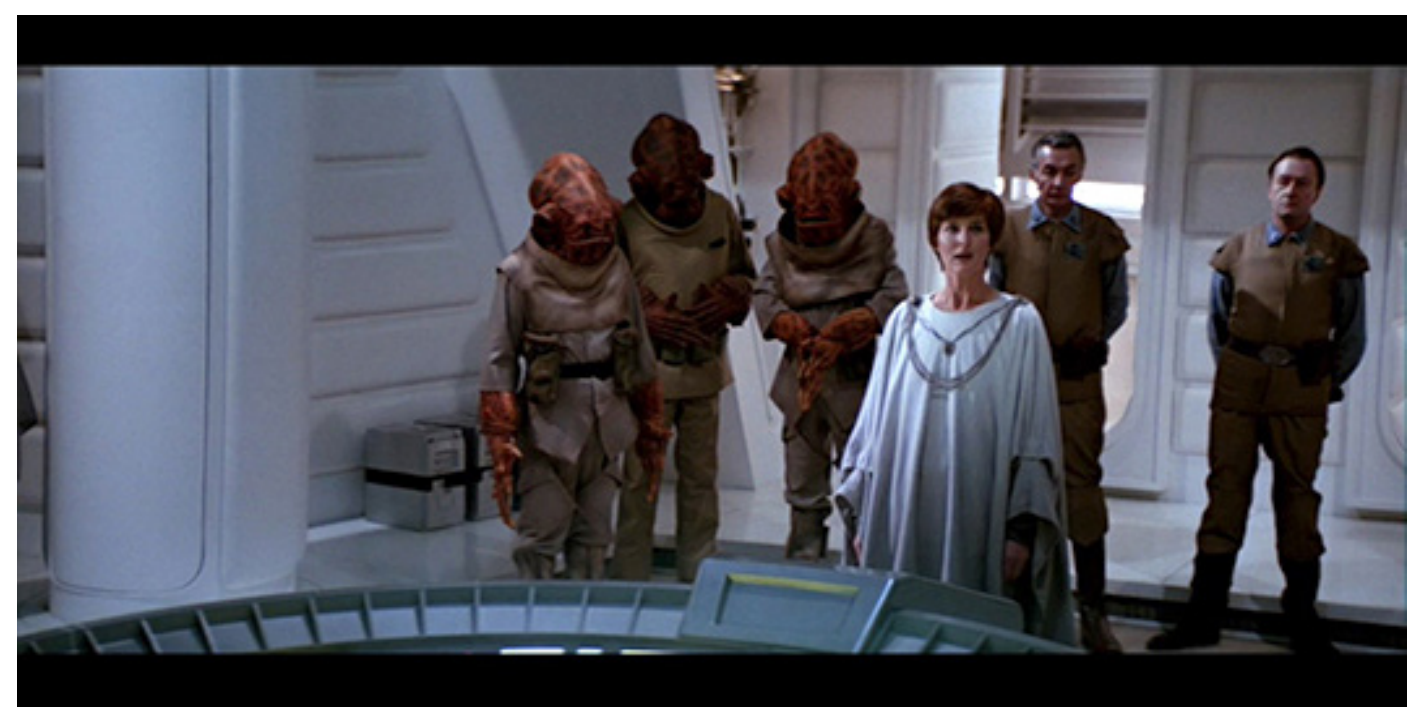

Kapinaliiton monikulttuurista korkeinta johtoa Jedin paluussa (1983). Kuva: Kuvakaappaus DVD:Itä. 
myös prinsessa Leian yläpuolelle hierarkiassa nähtävästi kohonnut nainen. ${ }^{10}$ Toisin sanoen brittiaksentit ovat ilmestyneet Kapinaliittoon suoraan huipulle. Silti loppujen lopuksi on oleellista, että Tähtien sodassa "Amerikka" voittaa "britit", aivan kuten historiassakin. Siksi tulkintamme mukaan kapinalliset puhuvat pääasiassa amerikkalaisaksentein myös trilogian lopussa.

\section{Valkoinen Imperiumi, monikulttuurinen Kapinaliitto}

Ryanin ja Kellnerin kyselytutkimuksessa (toteutettu vuonna 1986) Tähtien sodan nähneille kävi ilmi, että katsojat merkityksellistivät elokuvan asetelmat ja sanoman omiin poliittisiin kantoihinsa nojaten. Myös historiatietoisuudella oli vaikutusta. Tämän artikkelin kirjoittajien ja muun muassa yllä siteeratun Bellin tavoin osa Ryanin ja Kellnerin haastattelemista ihmisistä yhdisti kapinalliset Yhdysvaltojen itsenäisyyssotien sankareihin. (Krämer 2012, 65.) Elokuvaa katsottiin myös Yhdysvaltojen vähemmistöpolitiikan läpi. Imperiumin henkilöstö koostuu pelkästään ihmisistä, ja tarkemmin sanoen valkoihoisista miehistä. Kapinaliitto on viimeistään Imperiumin vastaiskusta alkaen monikulttuurinen, joka selittyy elokuvan tarinamaailmassa sillä, että se koostuu imperiumin ylivaltaa vastaan kamppailevista, eri planeetoilta tulevista henkilöistä.

Vaderia esittänyt David Prowse suhtautui huumorilla siihen, että hänen hahmoaan nimiteltiin "Darth Farmeriksi", "maanviljelijäksi" (Jones 2016, 285), johtuen hänen kouluttamattomasta, vahvasti regionaalisesta (Bristol) murteestaan. Ilmeisesti hän ei kuitenkaan osannut odottaa, että Lucas oli jo päättänyt korvata hänen repliikkinsä toisella näyttelijällä. Äänirooliin valittiin lopulta musta amerikkalaisnäyttelijä James Earl Jones. (Ks. Jones 2016, 298-302.) ${ }^{11}$ Ilmeisen tietoisena Jonesin ääniroolista afroamerikkalainen New Journal and Guide -lehti kirjoitti tuoreeltaan, että "Tähtien sota on yksi rasistisimmista elokuvista kautta aikain", koska pahuus pukeutuu mustaan ja "sen äänenä toimii musta mies", toinen afroamerikkalainen toimittaja taas vertasi elokuvan droidikaksikkoa orjiin, joista toinen puhuttelee valkoista miestä "Herraksi" (Master). Elokuvan nähtiin visioivan "tulevaisuuden imperiumin", jossa "ei tule olemaan" "mustia kansoja". (Sit. Jones 2016, 316-317.) On totta, että Imperiumi koostuu kokonaan "valkoisista miehistä", tosin sotilaallisen miehistön, eli iskujoukkojen (stormtroopers), ihonväristä on mahdoton sanoa mitään, sillä heitä ei elokuvissa koskaan nähdä ilman kypärää. ${ }^{12}$ Ylipäätään kritiikki on ymmärrettävää, sillä ainoa tärkeä tummaihoinen ihmishahmo sarjassa on Lando Calrissian (Billy Dee Williams), joka tosin kohoaa merkittävään tehtävään - kenraaliksi, valkoisen Han Solon tavoin ilman mitään sota-akatemiakoulutusta - Jedin paluussa. Siteeratut kritiikit ovat kuitenkin mielenkiintoisia aivan toisesta syystä.

\footnotetext{
10 Wilhelm $(2006,181-182)$ esittää mielenkiintoisen näkemyksen, jonka mukaan nimenomaan kapinalliset edustavat Tähtien sodassa toiseutta. Hän perustelee väitteen sillä, että kapinalliset muunlajisten (wookiet, ewokit) tavoin pukeutuvat tavallisiin vaatteisiin ja ovat osa luonnollista ympäristöä, kun taas oppressiivisen imperiumin edustajat pukeutuvat muovisiin panssareihin, joka erottaa heidät luonnosta. Argumentissa on selkeä rodullistava ulottuvuus, sillä imperiumi on täysin valkoihoinen.

11 Cushingin tapaan myös Prowse oli näytellyt Hammer-yhtiön elokuvissa. Lähinnä fyysisen olemuksensa takia (muun muassa Frankensteinin hirviö) Vaderin rooliin palkattu Prowse ei aavistanut, että Lucas oli päättänyt korvata hänen äänensä jollain toisella näyttelijällä. Jonesin mukaan Lucas oli harkinnut äänirooliin Orson Wellsia, mutta ehkä päätyi tuntemattomampaan näyttelijään siksi, että Wellsin ääni olisi ollut liian tunnistettava. Prowsen lausumia repliikkejä ja Jonesin näkemyksistä palkkaamisestaan ks. https://www.youtube.com/watch?v=KQFho0_G1VI\&t=39s (linkki tarkistettu 17.2.2020).

12 Mikäli mukailee edellä mainittua rotuargumenttia "pahasta mustasta miehestä", eli Vaderista, on huomattavaa, että tämä komentaa "valkoista" armeijaa.
} 


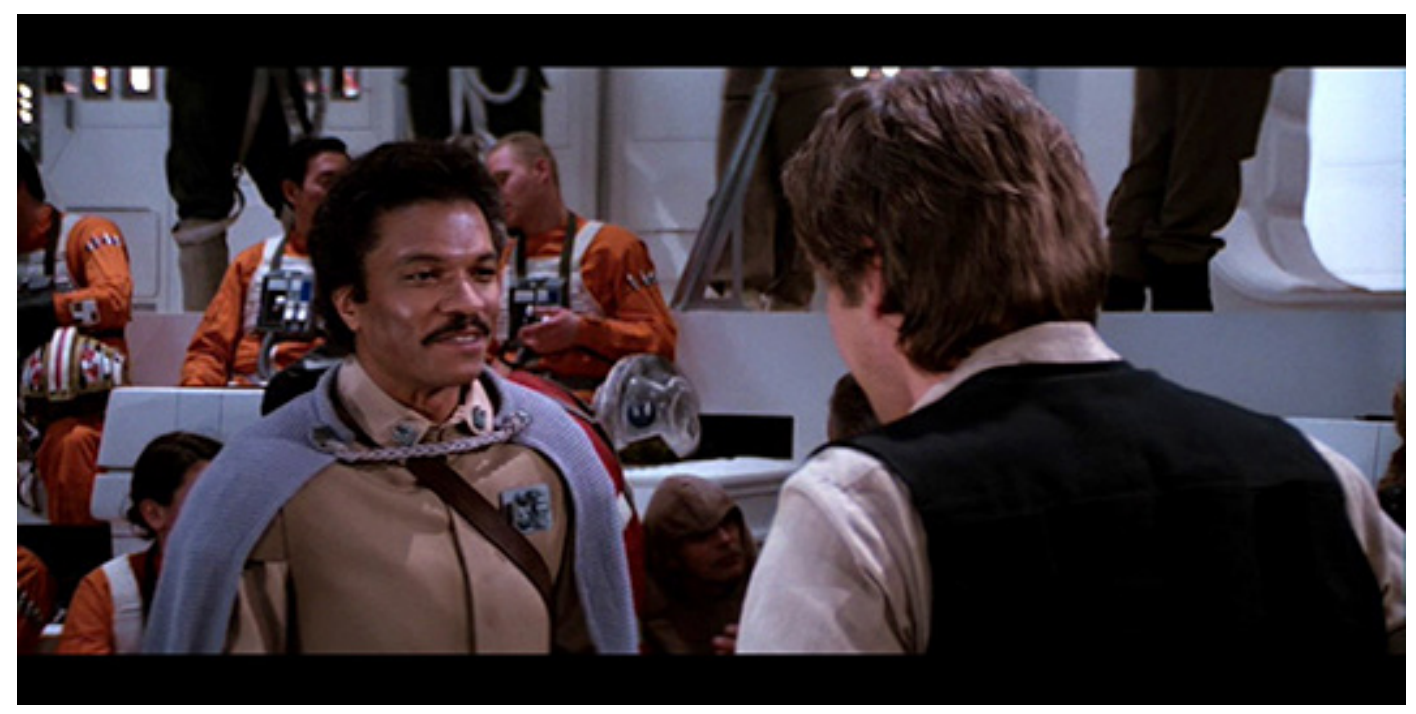

Kapinaliitossa tummaihoinenkin voi kohota kenraaliksi. Kenraalit Lando Calrissian (Billy Dee Williams) (vasemmalla) ja Han Solo (Harrison Ford) Jedin paluussa. Kuva: Kuvakaappaus DVD:Itä.

Ensinnäkin Vaderin (ääni)näyttelijän afroamerikkalaisuus jää puhtaasti katsojan pääteltäväksi, sillä kun tämän kasvot vihdoin nähdään Jedin paluussa käy ilmi, että hän on valkoinen (oletamme, että harvat olisivat muuta osanneet odottaakaan), pahoin runneltu vanhempaa keski-ikää oleva mies. Hänen "kasvojaan" (ja elokuvan loppuotoksessa "jedihaamuaan") näyttelee englantilainen Sebastian Shaw. Hahmo on kuin britti-imperiumi: menneestä voimantunnostaan ja vallastaan riisuttu arpeutunut hahmo, jonka menneisyyttä ei tosin voi sivuuttaa kuoleman hetkelläkään. Tappioonsa alistunut, kuolemaansa haluava Vader edustaa imperiumin lopullista tuhoa demokraattisemman maailman tieltä. Maailman, jossa tummaihoisillakin on mahdollisuus valtaan.

Tätä edellä mainitut afroamerikkalaiset kirjoittajat eivät voineet tietää, koska he eivät voineet tietää sitä, että Tähtien sodalle tehtäisiin jatko-osia, joissa luotaisiin pohja uudelle maailmanjärjestykselle. Heidän on täytynyt nähdä imperiumin tappio vain väliaikaisena, valkoisten ylivalta - jota kapinaliikekin eksplisiittisesti edusti valkoisine prinsessoineen ja miessankareineen - tulisi jatkumaan. Tähtien sodan Imperiumi edustaa kuitenkin mennyttä maailmaa, jonka kapinalliset tuhoavat omalla taistelullaan, aivan kuten Yhdysvallat irtautui britti-imperiumista.

Yhdysvallat on aina ollut demokratia, vaikka sille kaavailtiin itsenäistymisen jälkeen eurooppalaista monarkkia kuninkaaksi. ${ }^{13}$ Monarkia on kuitenkin osa amerikkalaista mielikuvitusta, kuten Yhdysvaltojen populaarikulttuurista voi todeta. Tähtien sota on pohjimmiltaan satu, lasten- tai kokoperheen seikkailuelokuva seikka, jota Lucas itsekin Jedin paluun tekemisen aikaan tekijätiimille korosti. Niinpä on luontevaa, että elokuvan naiskeskushahmo on prinsessa. Angloamerikkalaisessa historiakuvassa on kuitenkin mielenkiintoista, että Leia Organa on "amerikkalainen" prinsessa. Yhdysvalloissa ei ole koskaan ollut monarkiaa eikä täten prinsessaa, mutta sen populaarikulttuurissa viittaukset regaalisuuteen ovat olleet yleisiä: Elvis oli "rockin kuningas", Michael Jackson taas popin. Madonna on "popin kuningatar". Burger King -hampurilaisravintolaketjun ravintoloissa voi syödä hampurilaisia yhtä amerikkalaisen elämäntavan ja kulttuurin ikoneista - pahvikruunu päässä.

${ }^{13}$ Ks. esim. https://time.com/5459916/american-monarchy/ (linkki tarkistettu 22.2.2020). 
Silti monarkia assosioituu amerikkalaisessa mielikuvituksessa Eurooppaan, mikä selittyy historialla ja eri maista tulleiden siirtolaisten mukanaan tuomalla kulttuuriperinnöllä. ${ }^{14}$

Imperiumin hallitsija, keisari Palpatine (Ian McDiarmid) on ikääntynyt ja ylimielinen, stereotyyppinen "paha kuningas". Prinsessa Leia edustaa puolestaan hyvää, ja hän on nuori ja dynaaminen johtaja, ${ }_{1}^{15}$ joka pätee myös pelottomana soturina. Yhdysvaltalaisessa avaruussadussa "amerikkalainen" prinsessa onkin aivan luonnollinen asia, eikä asiaan edes kiinnittäisi huomiota, ellei tämä johtaisi taistelua huoliteltua brittienglantia puhuvien keisarin ja tämän hallintovirkamies- ja upseerikunnan johtamaa imperiumia vastaan. Leia edustaa monarkian idealisoitua kuvaa, keisari menneisyyteen juuttunutta, rappeutuvaa imperiumia. Allegoria Yhdysvaltojen ja Britannian kehitykseen maailmanvaltoina on ilmeinen.

\section{Lopuksi}

Palinin loppukaneetti Tähtien sodan ja Rakastettuni-elokuvan eroista oli, että kyllä jälkimmäisessäkin on hienoja toimintakohtauksia, "mutta tiedämmehän, että Britannia johtaa maailmaa päämäärättömissä räjähdyksissä" (Palin 2006, 475). Tähtien sodan lopun "räjähdys" ei sen sijaan ole "päämäärätön", sillä se syntyy Kuolontähden tuhosta. Palinin implisiittinen vertaus "amerikkalaisen räjähdyksen" tarkoituksenmukaisuudesta verrattuna brittiläiseen henkii brittiläistä pessimismiä ja tappiomielialaa. Tämä selittyy viime kädessä historiaa Oxfordissa opiskelleen Palinin tietoisuudesta Britannian ja Yhdysvaltojen vastakkaisista kehityksistä 1800- ja 1900-luvuilla. Lucasin luoma Tähtien sota -tarina kumpuaa sekin epäilemättä mielikuvitukseen syväjäljen jättäneestä historiallisesta kertomuksesta, jossa amerikkalaiskapinalliset lyövät britti-imperiumin sotajoukot.

Amerikkalaisten tapa mieltää "imperiumi" nimenomaan entiseksi siirtomaaisännäkseen on näkynyt esimerkiksi viimeksi mainitun käymien sotien uutisoinnissa. Britannian ja Argentiinan välillä vuonna 1982 käydyn Falklandin sodan aikana Newsweek uutisoi tapahtumista otsikolla "The Empire Strikes Back". Lehden kannessa oli kuva brittiläisestä lentotukialuksesta matkalla sotatoimialueelle. New York Times käytti täsmälleen samaa otsikkoa vuonna 1991 Persianlahden sodan yhteydessä. ${ }^{16}$ Vaikka viimeksi mainitussa olisi ollut kyse myös ensin mainittuun Newsweekin tunnettuun kansikuvajuttuun viittaamisesta, ennen kaikkea viittaus Tähtien sotaan on molemmissa tapauksissa selkeä ja amerikkalaisyleisölle tuttu. ${ }^{17}$

Tähtien sota -elokuvatrilogiasta (1977-1983) kertovan dokumentin (2004) nimi on "Empire of Dreams", unien tai unelmien imperiumi. Nimi viittaa trilogian läpi vaikuttavaan, sen lopussa tuhoutuvaan pahaan avaruusimperiumiin. Voisi ajatella, että hyvän voittoa pahasta juhlistavan moraalikertomuksen historiikin nimi viittaisi

\footnotetext{
${ }^{14}$ Brittirocktähti Elvis Costello (s. 1954) tiivisti tämänkaltaisen brittinäkemyksen amerikkalaisen kulttuurin banaaliudesta albumillaan King of America (1986) ja erityisesti sen kansikuvan avulla. Kuvassa Costello poseeraa kruunu päässä, katsoen ironisen näköisenä kameraan ikään kuin haastaen katsojan miettimään "Amerikan kuninkaan" idean keinotekoisuutta ja absurdiutta.

15 Nuorekkaan ja dynaamisen imagon omanneen John F. Kennedyn presidenttikautta kutsuttiin Camelotiksi, mikä viittaa myyttiseen brittien kuninkaaseen Arthuriin ja tämän hoviin.

${ }^{16}$ http://commonwealthstampsopinion.blogspot.com/2012/04/empire-strikes-back.html; https://www. nytimes.com/1991/03/10/magazine/the-empire-strikes-back.html (linkit tarkistettu 20.2.2020).

17 Salman Rushdien postkolonialistinen artikkeli vuodelta 1982 on nimeltään "The Empire Writes Back with Vengeance". Viittaus pari vuotta aiemmin ilmestyneeseen Imperiumin vastaiskuun on ilmiselvä. Ks. myös Wilhelm 2006, 177-178.
} 
jotenkin elokuvaan "hyviin", mutta nimi on osuva, sillä Tähtien sotaa hallitsee fasinaatio imperiumin käsitettä kohtaan. ${ }^{18}$ Imperiumi viittaa yleensä johonkin valtavaksi kasvaneeseen jättiläiseen. Sellainen Tähtien sota -franchise on itsekin, sillä uusia elokuvia ja varsinkin niiden oheistuotteita valmistetaan yhä. ${ }^{19}$

\section{Lähteet}

Barber, Siam (2013) The British Film Industry in the 1970s: Capital, Culture and Creativity. Lontoo: Palgrave Macmillan.

Bell, Chris (2019) Unions, Eccentrics and Alcohol: How Britain Built Star Wars. The Telegraph, 19.12.2019. Saatavilla: <https://www.telegraph.co.uk/films/0/unions-eccentrics-alcohol-britain-built-star-wars/> (linkki tarkistettu 19.2.2020).

Brooker, Will (2009) Star Wars. Lontoo: British Film Institute.

Curtis, James M. (1980) From American Graffiti to Star Wars. Journal of Popular Culture XIII:4, Spring 1980, 590-601.

Empire of the Dreams: The Story of the Star Wars Trilogy (2004) Ohjannut Kevin Burns ja Edith Becker. Star Wars Trilogia: bonusmateriaalit. DVD: Lucasfilm.

Geraghty, Lincoln (2006) Aging Toys and Players: Fan Identity and Cultural Capital. Teoksessa Matthew Wilhelm Kapell \& John Shelton Lawrence (toim.) Finding the Star Wars Franchise: Fans, Merchandise $\mathcal{E}$ Critics. New York: Peter Lang, 209-226.

Jones, Brian Jay (2016) George Lucas. Alkuteos: George Lucas: A Life. Suomentanut Sami Heino. Helsinki: Like.

Krauel, Richard (1911) Prince Henry of Prussia and the Regency of the United States, 1786. The American Historical Review Vol. 17, No. 1 (Oct., 1911), 44-51. Saatavilla: <https://www.jstor.org/ stable/1832837?seq=3\#metadata_info_tab_contents $>$ (linkki tarkistettu 7.1.2020).

Krämer, Peter (2012) Fighting the Evil Empire: Star Wars, the Strategic Defense Initiative, and the Politics of Science Fiction. Teoksessa Douglas Brode \& Leah Deyneka (toim.) Sex, Politics and Religion in Star Wars: An Anthology. Lanham: Scarecrow, 59-69.

McVeigh, Stephen P. (2006) The Galactic Way of Warfare. Teoksessa Matthew Wilhelm Kapell \& John Shelton Lawrence (toim.) Finding the Star Wars Franchise: Fans, Merchandise E Critics. New York: Peter Lang, 35-58.

Mähkä, Rami (2016) Something Completely Historical: Monty Python, History and Comedy. Turku: omakustanne.

O'Brien, Daniel (2000) SF:UK: How British Science Fiction Changed the World. Introduction by Kim Newman. Lontoo: Reynolds \& Hearn.

Peter Cushing on playing Grand Moff Tarkin on carpet slippers in STAR WARS - EPISODE IV: A NEW HOPE (2016) Youtube.com. Saatavilla: <https://www.youtube.com/watch?v=NdXLDvx_tHQ> (linkki tarkistettu 7.1.2020).

Rare Star Wars 1977 Alec Guinness Interview on Parkinson Talk Show. Youtube.com. Saatavilla: <https:// www.youtube.com/watch?v=3IxN0N35skE\&fbclid=IwAR150XH10jOOcXnq4K1AfvutRXygwfg6rrF1fu MIUiWH1jLsmKERNCGaM6A> (linkki tarkistettu 17.2.2020).

Wilhelm, Stephanie J. (2006) Imperial Plastic, Republican Fiber: Speculating on the Post-Colonial Other. Teoksessa Matthew Wilhelm Kapell \& John Shelton Lawrence (toim.) Finding the Star Wars Franchise: Fans, Merchandise \& Critics. New York: Peter Lang, 175-183.

\footnotetext{
18 Brooker $(2009,83)$ toteaa Lucasin olevan viimeistään 2000-luvulla "lähempänä [Tähtien sodan] Keisaria kuin nuorta elokuvaohjaajaa, joka vuonna 1967 teki elokuvan nimeltä The Emperor.

19 Kirjoittajille tässä artikkelissa käsitellyillä elokuvilla on siinä mielessä erityinen merkitys, että Tähtien sota oli ensimmäinen Tringhamin elokuvateatterissa näkemä "oikea" elokuva, Imperiumin vastaisku taas Mähkän.
} 